\title{
潜熱蓄熱材を用いた住宅用空気式床暖房システムの研究 RESIDENTIAL PNEUMATIC FLOOR-HEATING SYSTEM USING PHASE-CHANGE MATERIAL
}

\author{
中川純*1, 田辺新一*2 \\ Jun NAKAGAWA and Shin-ichi TANABE
}

\begin{abstract}
Research on a new residential phase-change material (PCM) floor heating system is conducted.
1. Using folded sheet metal, a floor heating system allows easy placement of PCM without making major changes to the general structure of wooden houses.

2. A floor model consisting of PCM and a water pack layer is designed. Additionally, case studies are conducted to confirm the application of physically reasonable trends.

3. Optimization of this system is defined, and a diagram was developed to help determine the PCM specification (phase change temperature and thickness) to realize optimization.
\end{abstract}

Keywords : Phase-Change Material, Floor-Heating, Simulation, Optimization 潜熱蓄熱材，床暖房，シミュレーション，最適化

\section{1. はじめに}

建築に転用可能な素材が開発されると、生産方法の合理化を行う だけではなく、素材の価値を高めるために、部品化や複合化のプロ セス 1)をたどることになる。潜熱蓄熱材（Phase-Change Material、以 下 PCM とする）は建築に転用された素材としては比較的新しい部 類に入るが、部品化や複合化の提案とともに、素材が持つ熱性状の シミュレーション、および熱的快適性や省エネルギーの観点から多 数の研究 3)17)がなされている。武田ら 4)5 は PCM を用いた暖房装置 を考案し、その効果をシミュレーションで確認した。高山らのは太 陽熱空気集熱器と PCM による外気負荷削減装置を開発し、実測と シミュレーションにより妥当性を確認した。草間ら 7) PCM 内装左 官材を開発し効果を確認した。いずれの研究も PCM を部品化・複 合化して効果を検証するものであり、遷移域における挙動、および 熱媒体との熱交換に関する議論がなされている。また、PCM はその 遷移域において単位体積当たりの熱容量が大きいため、木造住宅な ど熱容量の小さい建築の温熱環境を安定化する。さらに、熱源のピ ークシフトに寄与する可能性 ${ }^{8}$ )が示されており、現代においては重 要な技術と考えられている。しかし、PCM は水やコンクリートなど の安価な顕熱蓄熱材と比較すると、流通量に伴う製造コストが普及 の妨げとなっているため、部品化や複合化に際しては比較的安価な システムを構築する必要があると考えられる。

PCM を用いた床暖房において、篠崎ら 9は発熱体上部に PCM を 設置し、これらを顕熱蓄熱材であるコンクリートで覆ったシステム を考案し、設計および運用指針を示した。高瀬ら ${ }^{10}$ は温水を熱媒体
とした上で、すだれ状の配管と PCM を一体化したシステムを開発 し、熱交換量の優位性を確認した。また、室温と床表面温度の関係 からその有効性を示したが、システムに特殊な配管を採用している ため、現場での工種が増えると考えられる。

一方、藤田ら ${ }^{11}$ は住宅の床チャンバー内に PCM で構成された蓄 熱体を床下に設置した床下暖房において、床下温度と室温、および $\mathrm{PCM}$ の挙動について報告し、熱源と PCM の相変化温度、および使 用量についての決定法を示した。長野ら 12)はオフィス用の多孔 OA フロアにPCM を組み込んだシステムを考案し、数值計算を行った。 これらの床下空調や床吹出し空調は、床チャンバーに PCM の複合 部材を据えることで、通常の施工プロセスを変えることなく導入が 可能である。一般に、床チャンバーを利用して床材と対流方式で熱 交換する方法は、配管等の設備が不要なため、施工の手間とコスト において優位性があると考えられる。しかし、床チャンバーを利用 した空調において、床自体を暖める空気式床暖房に PCM を用いた 研究は極めて少ない。

本研究では PCM の時間推移を伴った熱性状に着目し、熱源に家 庭用エアコンを想定した上で、床を構築するための施工プロセスを 変更することなく、蓄熱材への加熱の手段を対流方式とした比較的 安価な住宅用空気式床暖房システムを開発した。また、実験に先だ って本システムの最適設計を行うために、放熱時間の長さと放射温 熱環境の安定性に着目して「最適化」を定義するとともに、シミュ レーションに基づいて最適を実現する PCM 仕様（厚みと相変化温 度）を決定するための線図を開発した。
*1 早稲田大学創造理工学研究科建築学専攻 博士後期課程

$* 2$ 早稲田大学創造理工学部建築学科 教授. 工博
Grad. Student, Dept. of Creative Science and Engineering, Waseda University, M.Eng. Prof., Dept. of Creative Science and Engineering, Waseda University, Dr.Eng. 


\section{PCM を用いた空気式床暖房システムの構成}

本研究で開発した空気式床暖房の構成を Fig.1 に示す。熱源には 家庭用エアコンを想定しており、気密性能と断熱性能が担保された 床チャンバー内に暖気を送ることで蓄熱層に熱を伝達し、床材に放 熱する。床材はフローリングとした。蓄熱層はPCM とし、必要に応 じて PCM の下に水封入層を配置する。床表面温度を安定化させる ため、PCM は床材裏面に配置する必要がある。また、システム全体 のコストを抑えるため、PCM を厚くすることのみで熱容量を担保す るのではなく、安価な水封入層を併用することで必要な熱容量を確 保する。蓄熱層から床材に熱を伝導するため、蓄熱層と床材を密着 する spring-effect heat-conductive metal plate（以下 SHP とする）を開 発した。SHP は $0.35 \mathrm{~mm}$ の安価な板金を一定の形状に折り曲げるこ とで、床材の裏面への密着性を担保するばね効果と、強度の向上を 実現した。また、通常の板金工事の範囲で製作が可能なため、水切 り等の工事と併用可能であり、施工の工種を増やす必要がない。

Fig.2 に SHP の断面形状を示す。PCM もしくは水封入層が任意の厚 さであっても、SHPのバネ効果により蓄熱層が床材の裏側に密着す る。さらに、板金を折り曲げることによって、SHP は住宅における 大引間の $910 \mathrm{~mm}$ スパンを飛ばすことが可能である。一般的な床工 事において、大引きの直交方向に根太を施工する際に SHP と蓄熱層 を根太間に配することで、通常の床工事の工程を変えることなく、 床材裏面に密着する蓄熱層を設けることが可能である。

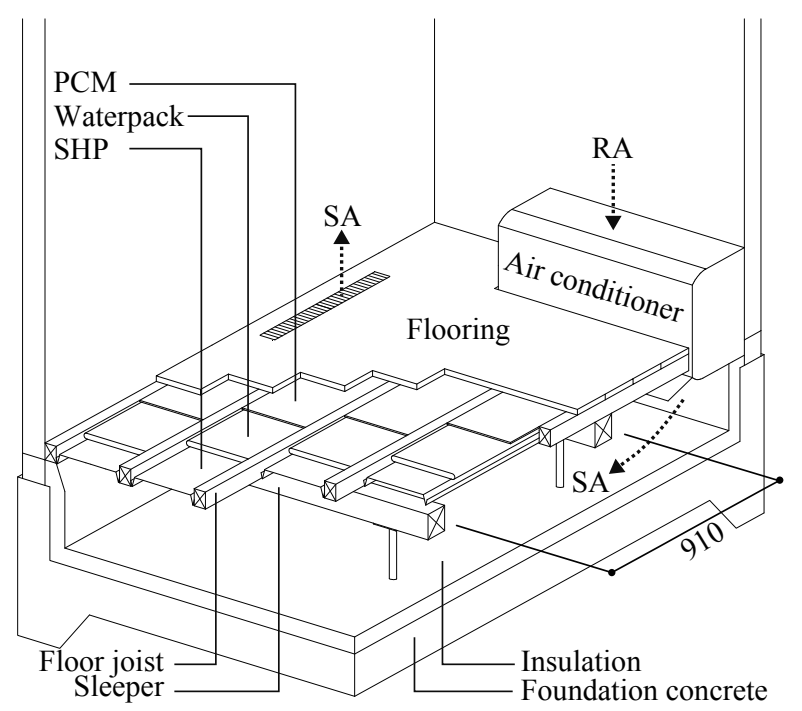

Fig.1 Structure of the proposed floor-heating system

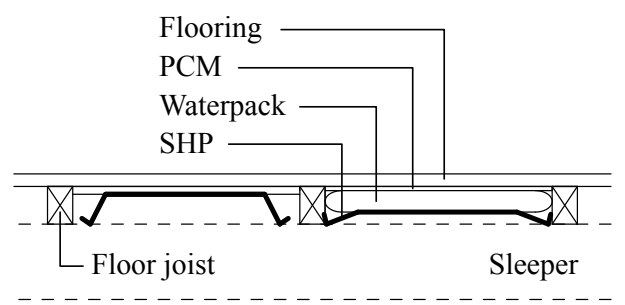

Fig.2 Section of the spring-effect heat-conductive metal plate

\section{3. モデルの作成}

前章で開発したシステムについての設計検討を可能にするため、 PCM の相変化現象を含む床の非定常伝熱を表現可能な物理モデル を開発した。

\section{1 定式化}

質点系でモデル化を行う。Fig.3 に床の熱流モデルを示す。灰色の 丸が境界条件であり、床上と床下の空気温度とする。周囲の物体は 空気温度に等しく、放射温度=空気温度と仮定する。放射熱伝達に関 しては放射熱伝達率を用いて計算を行った (パラメータは後述)。フ ローリング、PCM、水封入層はそれぞれ熱容量を持つ質点とし、二 重丸で表現する。SHP は熱伝導率が高く、厚さも $0.35 \mathrm{~mm}$ で熱容量 が小さく、熱的には影響が小さいため、本モデルでは考慮外とした。

フローリング、PCM、水封入層の温度 $\left(T_{f l} 、 T_{p c m} 、 T_{w a t}\right)$ の時間変 化はそれぞれ、相互の質点までの熱抵抗 $R\left[\mathrm{~m}^{2} \cdot \mathrm{K} / \mathrm{W}\right]$ と温度を用いて 式(1) 式(3)の微分方程式で表現できる。これを時間間隔 $\Delta t[\mathrm{~s}]$ で後退 差分化すれば式(4)、式(5)となり、現在温度 $T$ *から将来温度 $T$ を求 めることができる。また、上記の 3 点の温度が求まれば、熱容量を 持たない境界の温度 $\left(T_{u p} 、 T_{m i d 1} 、 T_{m i d} 、 T_{b k}\right)$ は隣接する質点の温度 から計算できる。なお、PCM または水封入層の厚みを 0 とする場合 には、式(5)において $\Delta t / C_{p c m}$ または $\Delta t / C_{\text {wat }}$ を 1 とし、各層の熱抵抗 $R_{p c m}$ または $R_{w a t}$ を 0 とすれば良い。また、計算の結果、PCM が前夕 イムステップと異なる相（固相、液相、遷移相）になった場合には、 異なる相の熱容量によって温度を更新してしまうことになるため、 過剩（または過小）な温度変化を式(6)で補正する注1)。 $T_{p c m}$ は補正前 の温度、 $T_{p c m, c o r}$ は補正後の温度、 $T_{p c}$ は相変化温度（凝固点または融 解点)、 $C_{p c m, \text { old }}$ は相変化前の相の熱容量、 $C_{p c m, n e w}$ は相変化後の相の熱 容量である。

境界条件は床上空気温度 $T_{a, u p}$ と床下空気温度 $T_{a, b k}$ である。ただし、 $T_{a, b k}$ は加熱運転時には給気温度 $T_{s p y}$ とし、運転停止時には $T_{a, u p}$ と等 しいと仮定した。

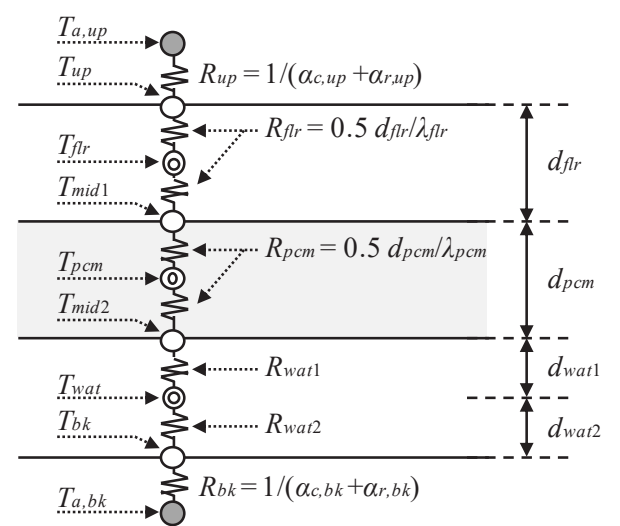

Fig. 3 Heat flow model

$$
\begin{gathered}
C_{f l r} \frac{d T_{f l r}}{d t}=\frac{T_{a, u p}-T_{f l r}}{R_{u p}+R_{f l r}}+\frac{T_{p c m}-T_{f l r}}{R_{f l r}+R_{p c m}} \\
C_{p c m} \frac{d T_{p c m}}{d t}=\frac{T_{f l r}-T_{p c m}}{R_{f l r}+R_{p c m}}+\frac{T_{w a t}-T_{p c m}}{R_{p c m}+R_{w a t 1}} \\
C_{w a t} \frac{d T_{w a t}}{d t}=\frac{T_{p c m}-T_{w a t}}{R_{p c m}+R_{w a t 1}}+\frac{T_{a, b k}-T_{w a t}}{R_{w a t 2}+R_{b k}}
\end{gathered}
$$




$$
\begin{aligned}
& {\left[\begin{array}{c}
T_{f l r}^{*}+a_{1} T_{a, u p} \\
T_{p c m}^{*} \\
T_{w a t}^{*}+c_{2} T_{a, b k}
\end{array}\right]=\left[\begin{array}{ccc}
1+a_{1}+a_{2} & -a_{2} & 0 \\
-b_{1} & 1+b_{1}+b_{2} & -b_{2} \\
0 & -c_{1} & 1+c_{1}+c_{2}
\end{array}\right]\left[\begin{array}{l}
T_{f l r} \\
T_{p c m} \\
T_{w a t}
\end{array}\right]} \\
& a_{1}=\frac{\Delta t / C_{f l r}}{R_{u p}+R_{f l r}} \quad, \quad b_{1}=\frac{\Delta t / C_{p c m}}{R_{f l r}+R_{p c m}}, \quad c_{1}=\frac{\Delta t / C_{w a t}}{R_{p c m}+R_{w a t 1}} \\
& a_{2}=\frac{\Delta t / C_{f l r}}{R_{f l r}+R_{p c m}}, \quad b_{2}=\frac{\Delta t / C_{p c m}}{R_{p c m}+R_{w a t 1}}, \quad c_{2}=\frac{\Delta t / C_{w a t}}{R_{w a t 2}+R_{b k}} \\
& T_{p c m, c o r}=T_{p c}+\frac{C_{p c m, o l d}}{C_{p c m, n e w}}\left(T_{p c m}-T_{p c}\right)
\end{aligned}
$$

\section{2 パラメータの設定}

1）床上空気の熱伝達率 $\alpha_{c, u p}$

床上空気の対流熱伝達率 $\alpha_{c, u p}\left[\mathrm{~W} /\left(\mathrm{m}^{2} \cdot \mathrm{K}\right)\right]$ は平均ヌセルト数 $N u[-]$ を用いて式(7)で計算した。 $\lambda_{a}[\mathrm{~W} /(\mathrm{m} \cdot \mathrm{K})]$ は空気の熱伝導率である。ま た、代表長さ $l_{s p n}[\mathrm{~m}]$ は、PCM の連続的な敷設が可能である大引間距 離 $(0.91 \mathrm{~m})$ とした。床上では床面の加温による自然対流により熱交 換が行われるとし、ヌセルト数は式(8)で計算した ${ }^{2)}$ 注 2$) 。 G r[-]$ と $P r$ [-]はそれぞれグラスホフ数とプラントル数であり、式(9)、式(10)で 計算した。ただし、 $g\left[\mathrm{~m}^{2} / \mathrm{s}\right]$ は重力加速度、 $l[\mathrm{~m}]$ は代表長さ、 $\beta[1 / \mathrm{K}]$ は体積膨張率、 $v\left[\mathrm{~m}^{2} / \mathrm{s}\right]$ は動粘性係数、 $\alpha\left[\mathrm{m}^{2} / \mathrm{s}\right]$ は熱拡散率、 $T_{h}\left[{ }^{\circ} \mathrm{C}\right]$ は 高温側温度、 $T_{c}\left[{ }^{\circ} \mathrm{C}\right]$ は低温側温度である。

$$
\begin{aligned}
& \alpha_{c, u p}=\frac{\lambda_{a} N u}{l_{s p n}} \\
& N u= \begin{cases}0.14(G r P r)^{1 / 3} & \left(T_{c}<T_{h}\right) \\
0.60(G r P r)^{1 / 5} & \left(T_{h} \leq T_{c}\right)\end{cases} \\
& G r=g l^{3} \beta\left|T_{h}-T_{c}\right| / v^{2} \\
& P r=v / \alpha
\end{aligned}
$$

2）水封入層における熱抵抗 $R_{w a t}$

水封入層では、下部の温度が上部よりも十分に高い場合など、一 定の条件を満たせば自然対流が生じる。この自然対流効果を反映す るため、式(11)に示すように平均ヌセルト数 $N u$ を用いて熱抵抗 $R_{\text {wat }}$ $\left[\mathrm{m}^{2} \cdot \mathrm{K} / \mathrm{W}\right]$ を計算した注 ${ }^{2)}$ 。ただし $\lambda_{\text {wat }}[\mathrm{w} /(\mathrm{m} \cdot \mathrm{K})]$ は水の熱伝導率、 $d_{\text {wat }}$ $[\mathrm{m}]$ は水封入層の厚みである。

$N u$ は、密閉無限水平流体層の計算式（式(12)、式(13) $\left.{ }^{2)}\right)$ に従い、 レイリー数 $R a_{l}[-]$ （式(14)）を用いて計算した。ただし、Ral が臨界 レイリー数 $R a_{c r}$ [-] (=1708)を下回る場合には自然対流は生じず、 $N u=1.0$ である。

$$
\begin{aligned}
& R_{\text {wat }}=\frac{d_{\text {wat }}}{\lambda_{\text {wat }} N u} \\
& N u=\left[\left\{1+1.466\left(1-\frac{R a_{c r}}{R a_{l}}\right)\right\}^{15}+\left\{\frac{R a_{l} f(\operatorname{Pr})}{1420}\right\}^{5}\right]^{1 / 15} \\
& f(\operatorname{Pr})=\left\{1+(0.5 / \operatorname{Pr})^{9 / 16}\right\}^{-16 / 9} \\
& \operatorname{Ra} a_{l}=\operatorname{Gr} \operatorname{Pr}
\end{aligned}
$$

3）床下の熱伝達率

加熱時には強制対流による熱伝達が生じると推測できる。床下面 の風速は大引や根太の存在により影響を受け、また、吹き出し口の 位置によっても変化するが、既往研究 ${ }^{13)}$ によれば平均的には $0.3 \sim 1.0$ $\mathrm{m} / \mathrm{s}$ 程度であり、対流熱伝達率 $\alpha_{c, b k}$ は $2 \sim 8 \mathrm{~W} /\left(\mathrm{m}^{2} \cdot \mathrm{K}\right)$ 程度の範囲にあ る。そこで本研究では $2 \mathrm{~W} /\left(\mathrm{m}^{2} \cdot \mathrm{K}\right)$ と $8 \mathrm{~W} /\left(\mathrm{m}^{2} \cdot \mathrm{K}\right)$ の場合についてそれ ぞれ計算を行って、感度を確認する方針とした。
Fig.1 に示したように、床チャンバーは断熱材で囲うため、放熱時 には床下空間と断熱材を介して熱が逃げることになる。従って、加 熱運転停止時の $R_{b k}$ は非密閉空気層と $60 \mathrm{~mm}$ のポリスチレンフォー ム (熱伝導率 $=0.034 \mathrm{~W} /\left(\mathrm{m}^{2} \cdot \mathrm{K}\right)$ ) の合成抵抗である $1.8 \mathrm{~m}^{2} \cdot \mathrm{K} / \mathrm{W}$ とし た。

4） PCM の物性とモデル化

PCM は相変化に伴い物性が変化する。本モデルで用いた熱物性を Table 1 に示す。計算の各タイムステップにおいて PCM の温度を確 認し、相変化時には Table 1 の熱物性を再設定した。厳密には、配合 を変えて PCM の相変化温度を変化させると、相変化に要する熱も 変わるが、いくつかの材料を確認したところ、10\%以内の差異であ ったため、以下の検討では相変化温度の違いに関わらず Table 1 の 熱物性を共通して用いた。

Fig.4 に本研究における PCM のモデル化の方法を示す。状態変化 に必要なエネルギーを表現するために、遷移域において固相および 液相とは異なる比熱で計算を行った。このような手法で用いる比熱 は「見かけの比熱」と呼ばれており、多くの既往研究において用い られている手法である。相変化中の見かけの比熱の設定方法に関し てはいくつもの提案 13) 14) 15) 16) 17)があるが、本研究では相変化中で一

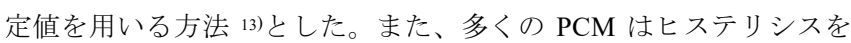
持ち、凝固の開始・終了点と融解の開始・終了点が異なるため、融 解途中に凝固過程に移行する場合や、逆の場合などには、ヒステリ シスの存在が計算結果に大きく影響する可能性がある ${ }^{3)}$ 。しかし、 本研究は設計線図の作成が主目的であり、完全に融解した後に完全 に凝固する 1 サイクルの運転を前提とした計算を行う。従って、本 研究のモデルでは、凝固開始点 $=$ 融解終了点 $=T_{f r z}\left[{ }^{\circ} \mathrm{C}\right]$ 、融解開始点 $=$ 凝固終了点 $=T_{m l t}\left[{ }^{\circ} \mathrm{C}\right]$ とし、開始と終了の温度差は $0.5^{\circ} \mathrm{C}$ とした。

Table 1 Thermophysical properties of phase change material

\begin{tabular}{l|c|c|c}
\hline & Solid & Equilibrium & Liquid \\
\hline \hline volumetric specific heat $\left[\mathrm{kJ} /\left(\mathrm{m}^{3} \cdot \mathrm{K}\right)\right]$ & 1,500 & - & 1,500 \\
\hline latent heat $\left[\mathrm{kJ} / \mathrm{m}^{3}\right]$ & - & 170,576 & - \\
\hline heat conductivity $[\mathrm{W} /(\mathrm{m} \cdot \mathrm{K})]$ & 0.432 & 0.270 & 0.229 \\
\hline
\end{tabular}

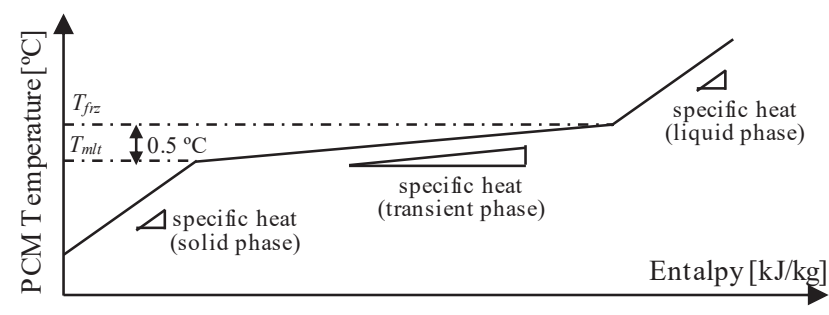

Fig.4 Method of modeling PCM

5）その他のパラメータ

床上下表面の放射熱伝達率は、放射率を 0.9 、平均温度を $300 \mathrm{~K}$ と し、 $5 \mathrm{~W} /\left(\mathrm{m}^{2} \cdot \mathrm{K}\right)$ で固定値とした。床材の熱伝導率 $\lambda_{f r}$ は $0.12 \mathrm{~W} /(\mathrm{m} \cdot \mathrm{K})$ 、 容積比熱は $500 \mathrm{~kJ} /\left(\mathrm{m}^{3} \cdot \mathrm{K}\right)$ 、厚み $d_{f r}$ は $0.015 \mathrm{~m}$ とした。従って、熱抵 抗 $R_{f r}$ は $0.125 \mathrm{~m}^{2} \cdot \mathrm{K} / \mathrm{W}$ 、熱容量 $C_{f l r}$ は $7,500 \mathrm{~J} /\left(\mathrm{m}^{2} \cdot \mathrm{K}\right)$ である。

\section{3 ケーススタディ}

床の層の構成を変えて傾向を確認した。シミュレーションのケー ス一覧を Fig.5 に示す。Case A が基準であり、PCM 厚を 2 倍にした 
ものが Case B、PCM を取り除いたものが Case C、水封入層を取り 除いたものが Case D である。これらの床に対して 3.5 時間の加熱と 10.5 時間の放熱を行った。床下空気温度は加熱中が $45^{\circ} \mathrm{C}$ 、放熱中が $25^{\circ} \mathrm{C}$ 、床上空気温度は $25^{\circ} \mathrm{C}$ で一定とした。

床上からの放熱の熱流と PCM の温度の推移を Fig.6 に示す。基準 である Case A は加熱開始後 30 分程度で相変化が始まり、2 時間程 度で完全に液相となる。PCM を2 倍に増やした Case B では、加熱 終了直前に液相となり、潜熱容量を使い切っているため、Case A よ りも安定した放熱が行われる時間が長い。水だけの Case C は加熱時 に最も大きく温度が上昇し、放熱の速度もCase A より早い。水封入 層がない Case D は、開始 2 時間程度で PCM が液相となり、3 時間 程度で定常状態となる。 $\mathrm{PCM}$ の凝固開始点は $30.0{ }^{\circ} \mathrm{C}$ 、終了点は $30.5^{\circ} \mathrm{C}$ であり、PCM を含む Case A, B, D のいずれも $30.0 \sim 30.5^{\circ} \mathrm{C}$ の 範囲で温度変化の推移がほぼ水平に広がっていることが確認できる。

\begin{tabular}{|c|c|c|c|c|c|c|c|}
\hline \multicolumn{2}{|c|}{$\underline{\text { Case A }}$} & \multicolumn{2}{|c|}{$\underline{\text { Case B }}$} & \multicolumn{2}{|c|}{$\underline{\text { Case C }}$} & \multicolumn{2}{|c|}{$\underline{\text { Case D }}$} \\
\hline Wood & $15 \mathrm{~mm}$ & Wood & $15 \mathrm{~mm}$ & Wood & $15 \mathrm{~mm}$ & Wood & $15 \mathrm{~mm}$ \\
\hline PCM & $5 \mathrm{~mm}$ & PCM & $10 \mathrm{~mm}$ & & & $\mathrm{PCM}$ & $5 \mathrm{~mm}$ \\
\hline $\begin{array}{l}\text { Water } \\
\text { pack }\end{array}$ & $30 \mathrm{~mm}$ & $\begin{array}{c}\text { Water } \\
\text { pack }\end{array}$ & $25 \mathrm{~mm}$ & pack & & & \\
\hline
\end{tabular}

Fig.5 Simulation cases

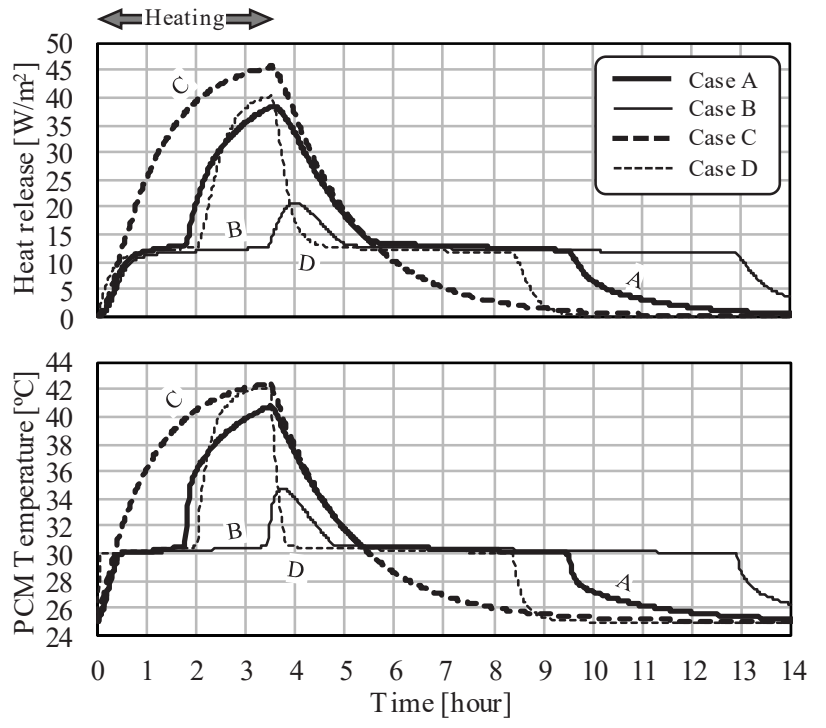

Fig.6 Heat release from floor upper surface and PCM temperature

\section{4. 設計法の検討}

本システムを設計する際には、具体的な PCM の仕様（相変化温 度と厚み）を選択する必要がある。そこで、本章では、本システム における最適化の定義を行うとともに、前章の物理モデルを用いて 最適な PCM 仕様を導き出す手法について検討した結果を報告する。

\section{1 「最適化」の定義}

PCM を導入した床の上側表面温度の時間推移は、理想的には Fig.7 のようになる。 $\Delta t_{c h g}$ の範囲では、床下に暖気を流して加熱を行って いる。加熱開始時の PCM の状態が固相であったとすると、加熱に よって温度が上昇するため、表面温度も速やかに上昇する。PCM の
温度が上がり遷移域に入ると、PCM の温度がほぼ一定となり、表面 温度も安定する。さらに加熱を続けると PCM が液相に移り、再び 温度上昇が加速するため、表面温度も急速に高まる。加熱を停止す ると、以上の逆の経過をたどる。

PCM を導入することの 1 つの大きな目的は温熱環境の安定化に あるため、設計条件としては、目標とする床表面温度の範囲を決め る必要がある。これが Fig.7 の下限温度 $T_{\text {llmt }}\left[{ }^{\circ} \mathrm{C}\right]$ と上限温度 $T_{\text {ulmt }}\left[{ }^{\circ} \mathrm{C}\right]$ である。そして、この温度帯で放熱できた時間数を有効放熱時間 $\Delta$ $t_{r l s}[\mathrm{sec}]$ と定義する（Fig.7 着色部）。現実には加熱時間帯（ $\Delta t_{c h g} ）$ に おいても上下限範囲内の表面温度で放熱が行われるが、この時間は $\Delta t_{r l s}$ に含めない。加熱時間帯の放熱を有効とみな寸のであれば、そ もそも蓄熱材を介さずに直接に空気による対流暖房を行うか、熱容 量の小さいパネルによる放射暖房を行う方が効率的であるためであ る。PCM という蓄熱材を用いたシステムの評価であるため、加熱が 終了した後の放熱時間の挙動に対して「最適」を定義することが合 理的であると思われる。

$\Delta t_{c h g}$ の間に床下から床に対して供給された熱量を $Q_{c h g}\left[\mathrm{~J} / \mathrm{m}^{2}\right]$ とす る。また $\Delta t_{r l s}$ を $Q_{c h g}\left[\mathrm{~J} / \mathrm{m}^{2}\right]$ で除した值を、安定化効率 $\eta_{s t b}\left[\mathrm{~s} /\left(\mathrm{J} / \mathrm{m}^{2}\right)\right]$ と 定義する (式(15))。すなわち $\eta_{s t b}$ は、床下からの単位投入熱量あた りで、設計目標範囲内に床上表面温度がどれだけ維持できたかを表 す指標である。本研究では、この $\eta_{s t b}$ を最大化することを最適化と 定義する。この他にも、例えば $\Delta t_{\text {chg }}$ の間に床上に放熱された熱量を 式(15)の分子にとることで無次元の指標とすることも考えられるが、 これでは許容温度範囲内で短期的に大きく放熱した方が、長期的に 安定的に放熱するよりも高く評価される可能性がある。従って、温 熱環境の安定化という PCM の評価指標としては妥当ではないと思 われる。

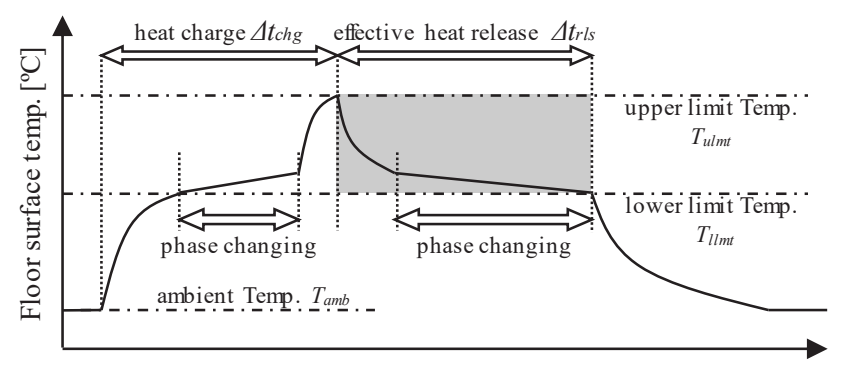

Fig.7 Heat release from floor upper surface

$$
\eta_{s t b}=\frac{\Delta t_{r l s}}{Q_{c h g}}
$$

\section{2 設計条件}

PCM 仕様の設計に先立ち決定しておく条件は、室温、床上表面の 上下限温度、放熱時間の 3 つである。室温は一般の対流方式の空調 システムの場合と同様に決定する。床上表面温度は、全体の空調シ ステムの構成によって異なる。仮に、主たる暖房は室内設置の家庭 用エアコンなどで行い、床暖房システムには放射温熱環境の安定化 としての役割を担わせるのであれば、床表面温度は室温に対してあ まり高い值に設定する必要はない（室温 $22{ }^{\circ} \mathrm{C}$ に対して床表面温度 $24{ }^{\circ} \mathrm{C}$ など)。逆に、補助的な加熱源を持たず、床暖房システムにす 
べての暖房機能を担わせるのであれば、室内空気に対して十分な熱 流が発生するだけの高い表面温度を設定する必要がある (室温 $22^{\circ} \mathrm{C}$ に対して床表面温度 $30^{\circ} \mathrm{C}$ など)。放熱時間は居住者の生活スケジュ ールに即して決定する。なお、室温は蓄放熱時間帯中、一定に保た れることを前提とするため、例えば外出時に蓄熱を行って䚻宅後の 放熱を期待するというような、大きく室温が摇れ動くことを前提と した運用に対しては本研究で作成する線図はそのまま適用すること はできない注3)。

\section{3 相変化温度の決定方法}

PCM は配合によって相変化温度を調節することができる。そこで、 凝固点 $T_{f r z}$ と PCM 厚を変化させて蓄熱時間ごとに安定化効率 $\eta_{s t b}$ を 計算した結果を Fig. 8 に示す。ただし $d_{\text {wat } 1}$ と $d_{\text {wat } 2}$ は $5 \mathrm{~mm} 、 T_{a, b k}$ と $T_{a, u p}$ は $24^{\circ} \mathrm{C} 、 T_{u l m t}$ は $28^{\circ} \mathrm{C} 、 T_{l l m t}$ は $26^{\circ} \mathrm{C} 、 T_{s p y}$ は $45^{\circ} \mathrm{C}$ とした。いず れの凝固点においても、それぞれの PCM 厚で $\eta_{s t b}$ が極大值を示寸蓄 熱時間 $\Delta t_{c h g}$ が存在することがわかる。また、PCM の厚みが増えると 極大值を示す $\Delta t_{\text {chg }}$ は長い側へ移動する。これは、大きな PCM の蓄 熱量を活用しきるだけの十分に長い蓄熱時間が必要となるためであ る。

上記の条件においては、多くの $\mathrm{PCM}$ 厚で凝固点が $30^{\circ} \mathrm{C}$ のときに $\eta_{s t b}$ が極大值を取る。また、 $31{ }^{\circ} \mathrm{C} や 32{ }^{\circ} \mathrm{C}$ における $\eta_{s t b}$ に比較して、 $29^{\circ} \mathrm{C}$ における $\eta_{s t b}$ は非常に小さい。すなわち、最適な凝固点に比較 して低い温度を設定してしまうと $\eta_{s t b}$ が急速に低下寸る。これは以 下の理由による。有効放熱時間 $\Delta t_{r l s}$ を最大化するためには、相変化 が有効放熱時間内に行われることが必要である。一方で、Fig.7 から わかるように、無駄な加熱エネルギーの発生を回避するためには、 蓄熱完了時点での表面温度は上限温度 $T_{u l m t}$ を下回る必要がある。従 って、放熱完了時の表面温度が下限温度と一致するとき、 $\Delta t_{r l s}$ は最 大化することになる。このため、表面温度の推移は Fig.7 に示すよ うに下限表面温度ぎりぎりを沿うことになる。このとき、凝固点を 低く変更すると、相変化中の表面温度の多くが下限表面温度を下回 ることになる。これが最適温度よりも凝固点を低く設定した場合に $\eta_{s t b}$ が大きく低下する理由である。

設計条件に合わせてシミュレーションを繰り返せば、最適な凝固 点を把握することができるが、簡易的には以下の方法で推定できる。 仮に最適な PCM が選定されたとすれば、上記の通り、有効放熱時 間完了時点においては、床表面温度はほぼ一定の值を取り続けてき たことになる。従って、表面の熱流は定常状態に近いと言える。そ こで、PCM から床上空気までの定常熱流式（式(16)）を用いて、床 上表面温度 $T_{u p}$ に下限温度 $T_{l l m t}$ を代入して PCM 温度 $T_{p c m}$ について解 けば式(17)が得られ、これが最適凝固点 $T_{f r z, o p t}$ の近似值である。式(17) の右辺の $R_{p c m}$ は PCM の厚みが確定しなければ得られないが、床材 の熱抵抗 $R_{f t r}$ に比較して小さく、また、先の検討により、凝固点が大 きく算出されることは安全側であることがわかっているため、十分 に大きい PCM 厚を仮定 (本研究では $20 \mathrm{~mm}$ ) して計算を行う。式 (17)を用いて、室温と下限表面温度から最適凝固点を得る線図を作 成した結果を Fig.9 に示す。Fig.8 の計算条件である $T_{a, u p}=24{ }^{\circ} \mathrm{C}$ と $T_{l l m t}=26^{\circ} \mathrm{C}$ を本図にあてはめて凝固点を求めると $T_{f r z, o p t} \approx 30^{\circ} \mathrm{C}$ とな り、ほぼ最適な温度が得られることがわかる。

$$
\frac{T_{u p}-T_{a, u p}}{R_{u p}}=\frac{T_{p c m}-T_{u p}}{2 R_{f l r}+R_{p c m}}
$$

$$
T_{f r z, o p t} \approx T_{l l m t}+\frac{2 R_{f l r}+R_{p c m}}{R_{u p}}\left(T_{l l m t}-T_{a, u p}\right)
$$

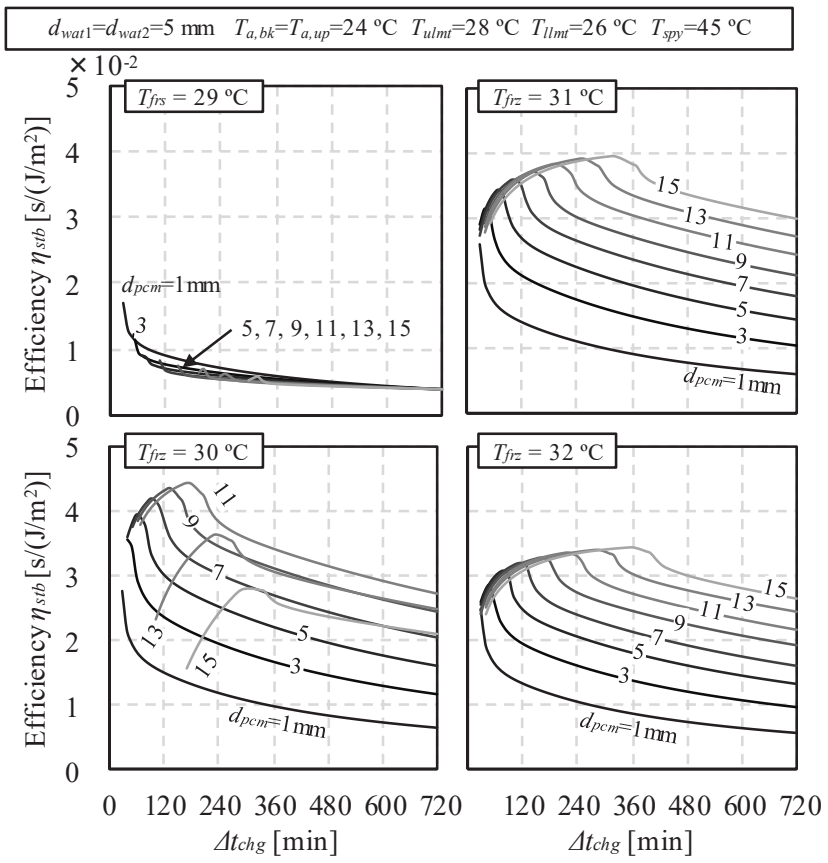

Fig. 8 Heat charging time and efficiency

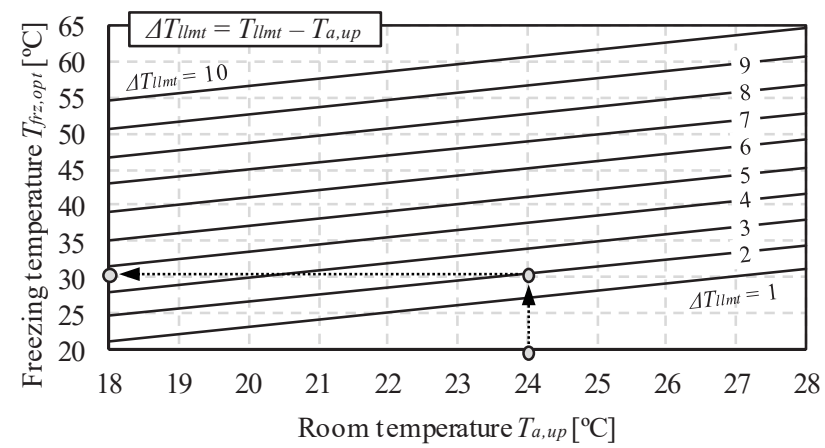

Fig.9 Optimum freezing-temperature selection chart

\section{$4.4 \mathrm{PCM}$ 厚の決定方法}

前章で開発したモデルを用いて、いくつかの条件において安定化 効率 $\eta_{s t b}$ が最大化する PCM 厚と、そのときに必要となる蓄熱時間を 計算した。計算結果を Fig.10 Fig.13に示す。ただし $T_{u l m t}=T_{l l m t}+5^{\circ} \mathrm{C}$ と した。Fig.10 と Fig.11 は加熱時の床下対流熱伝達率を $2 \mathrm{~W} /\left(\mathrm{m}^{2} \cdot \mathrm{K}\right)$ と した場合、Fig.12 と Fig.13 は $8 \mathrm{~W} /\left(\mathrm{m}^{2} \cdot \mathrm{K}\right)$ とした場合の結果である。 左列と右列はそれぞれ水封入層の厚みを $0 \mathrm{~mm}$ とした場合と $20 \mathrm{~mm}$ とした場合である。また、床下給気温度 $T_{s p y}$ と室温 $T_{a, u p}$ との温度差 を変化させて上下段に表示した。同じ図中に描かれている複数の線 は、表面温度下限值と室温の差を表している。

設計放熱時間（横軸）が長くなるほど、必要な PCM が厚くなり、 蓄熱時間も長くなることがわかる。また、対流熱伝達率が大きい場 合 $\left(8 \mathrm{~W} /\left(\mathrm{m}^{2} \cdot \mathrm{K}\right)\right)$ には熱流が大きくなるため、PCM 厚を増やし、短 めの蓄熱時間で運用することが最適となることがわかる。

具体例を上げて図表の使用方法を解説する。暖房時の設計室温を $23^{\circ} \mathrm{C}$ 、床下給気温度を $38^{\circ} \mathrm{C}$ 、放熱時間を $240 \mathrm{~min}$ とする。対流熱伝 
達率を $2 \mathrm{~W} /\left(\mathrm{m}^{2} \cdot \mathrm{K}\right)$ とし、水封入層を導入しないとすれば、Fig.10の 左上の線図を用いる。床上表面温度下限值を $24{ }^{\circ} \mathrm{C}\left(\right.$ 室温 $\left.+1{ }^{\circ} \mathrm{C}\right)$ と すれば、横軸の $240 \mathrm{~min}$ の值を読み取り、 $\mathrm{PCM}$ の最適厚みは $0.8 \mathrm{~mm}$ となる。同様に床上表面温度下限值を $25^{\circ} \mathrm{C}\left(\right.$ 室温 $\left.+2{ }^{\circ} \mathrm{C}\right)$ とすれば、 最適厚みは $1.7 \mathrm{~mm}$ となる。このとき、必要な蓄熱時間は Fig.11を 用いることでそれぞれ、約 $30 \mathrm{~min}$ と $120 \mathrm{~min}$ となる。一方で、床上

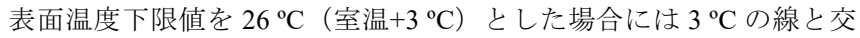
わらず、解が存在しない。これは、室温との温度差が大きいために 床上への放熱が大きくなり、蓄熱が完了しない（PCM が相変化する まで加熱できない）ということを意味している。

水封入層を導入する場合も線図の使用方法は同じであるが、描か れた線が原点から離れている点に注意を要する。例えば、Fig.12の
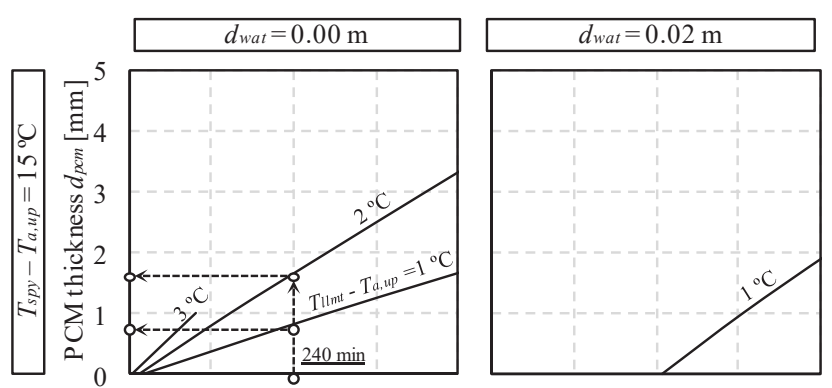

$\square$
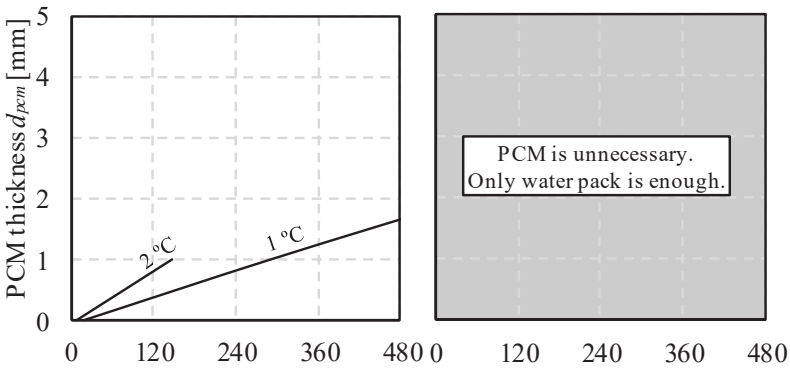

eff. heat release time $\Delta t r l s[\mathrm{~min}]$ eff. heat release time $\Delta t_{r l s}[\mathrm{~min}]$

Fig.10 optimum pcm thickness $\left(\boldsymbol{\alpha}_{c, b \boldsymbol{k}}=2 \mathrm{~W} /\left(\mathrm{m}^{2} \cdot \mathrm{K}\right), \boldsymbol{T}_{a, b \boldsymbol{k}}=\boldsymbol{T}_{a, u p}\right)$

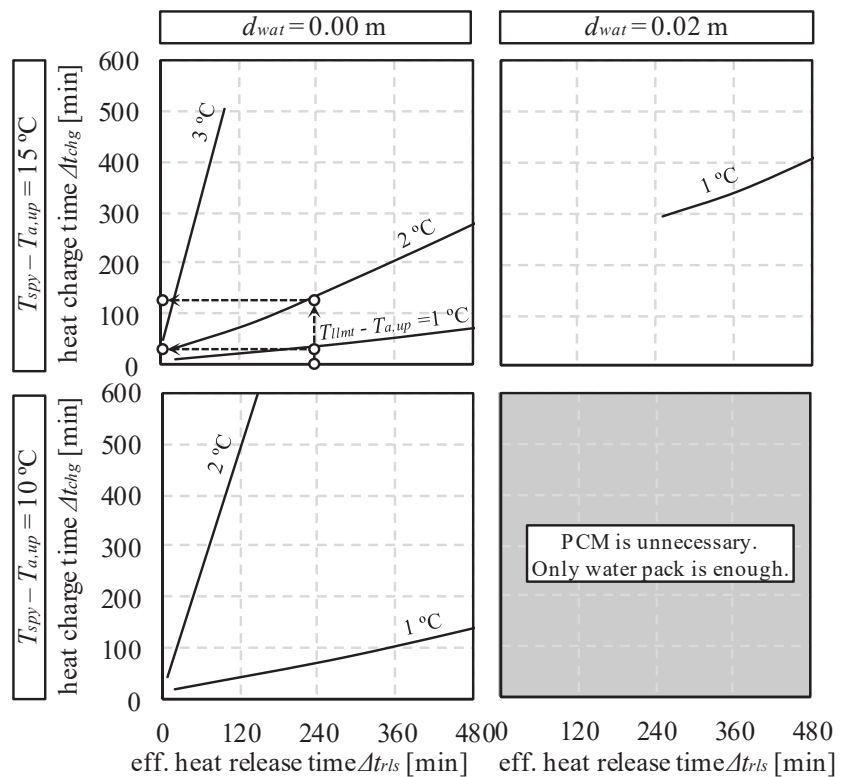

Fig.11 optimum heat charge time $\left(\boldsymbol{\alpha}_{c, b k}=2 \mathrm{~W} /\left(\mathrm{m}^{2} \cdot \mathrm{K}\right), \boldsymbol{T}_{a, b k}=\boldsymbol{T}_{a, u p}\right)$
右上の線図で放熱時間が $240 \mathrm{~min}$ の場合の值を読むと、温度差が 1 ${ }^{\circ} \mathrm{C}$ の場合には最適厚みは $0 \mathrm{~mm}$ である。これは、60 min の放熱時間 を得るためには、 $20 \mathrm{~mm}$ の水封入層があれば十分で、PCM の導入が 不要であるということを意味している。

Fig.10 Fig.13 は、放熱時の床下空気温度 $T_{a, b k}$ が床上空気温度 $T_{a, u p}$ と等しいと仮定した線図であり、階下も空調空間である 2 階の床を 想定している。しかし、1 階床のように床下温度が外気に近く温度 差が大きい場合には階下への相対的に放熱量が大きくなり、最適厚 が変化することが予想される。そこで、床上下温度差を $20{ }^{\circ} \mathrm{C} に し$ た場合の計算も行った。結果を Fig.14 Fig.17 に示す。階下への放熱 量が大きくなった結果、相対的に厚い PCM が最適となる傾向が表 れている。
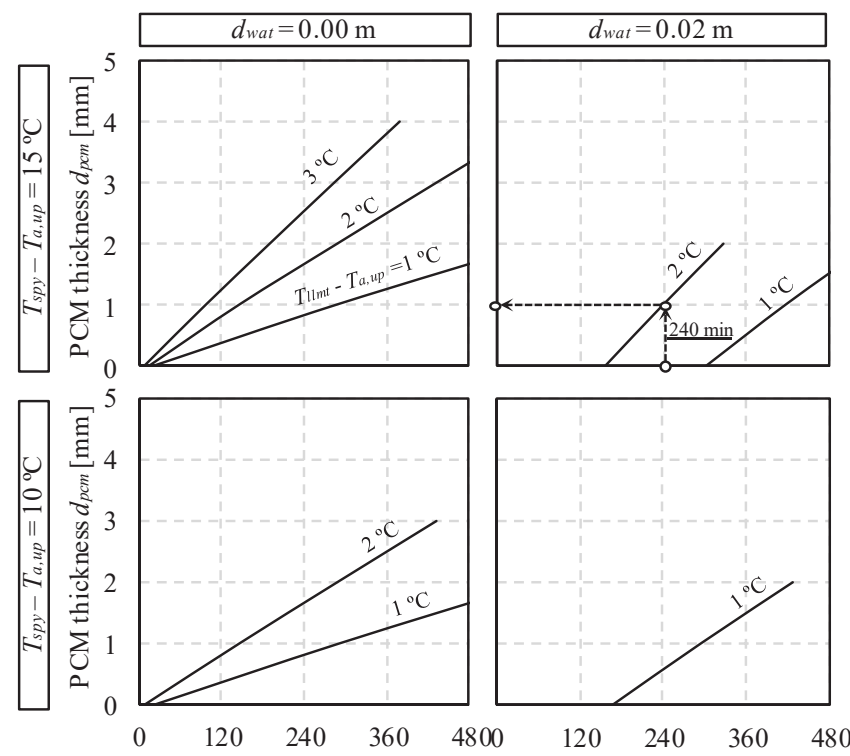

eff. heat release time $\Delta t_{r l s}[\mathrm{~min}]$ eff. heat release time $\Delta t_{r l s}$ [min]

Fig.12 optimum pcm thickness $\left(\boldsymbol{\alpha}_{c, b \boldsymbol{k}}=8 \mathrm{~W} /\left(\mathrm{m}^{2} \cdot \mathrm{K}\right), \boldsymbol{T}_{a, b \boldsymbol{k}}=\boldsymbol{T}_{a, u p}\right)$
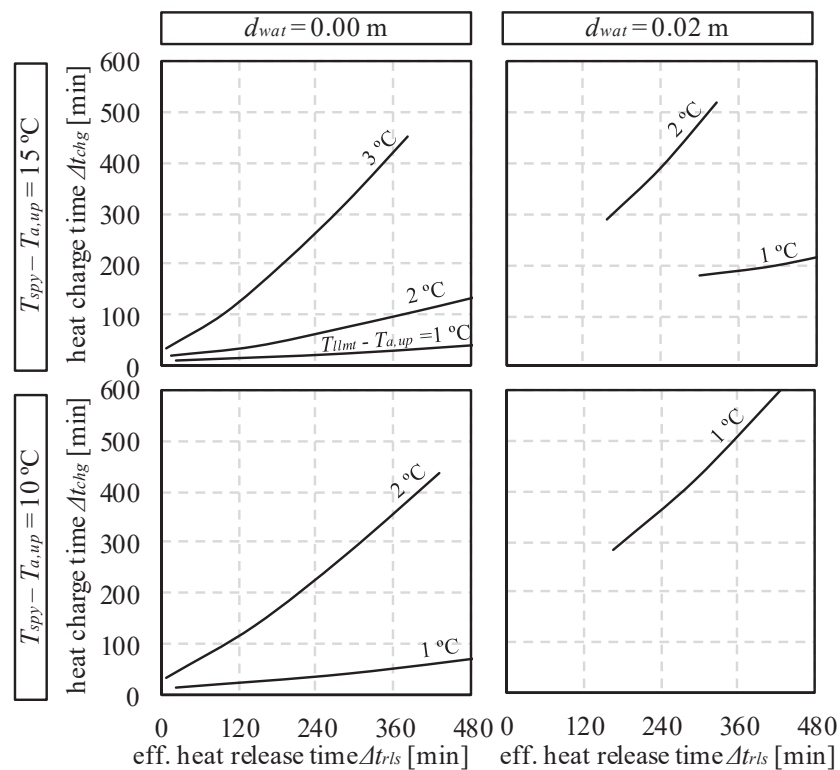

Fig.13 optimum heat charge time $\left(\boldsymbol{\alpha}_{c, b k}=8 \mathrm{~W} /\left(\mathrm{m}^{2} \cdot \mathrm{K}\right), \boldsymbol{T}_{a, b k}=\boldsymbol{T}_{a, u p}\right)$ 


\section{5. まとめ}

本研究では、比較的安価な新しい住宅用の潜熱蓄熱式床暖房シス テムについて報告を行った。

1）安価な板金を一定の形状に折り曲げることで強度を確保し、大引 の $910 \mathrm{~mm}$ スパンを飛ばすことが可能で、かつ、床材と蓄熱材の 密着性を担保できる床暖房システムを開発した。

2）本システムの最適設計を可能とするために、PCM と水封入層 を含む床の質点系モデルを構築した。また、ケーススタディを行 い、物理的に妥当な傾向が表現されていることを確認した。

3）本システムの「最適化」を定義するとともに、上記のモデルを用 いることで、最適化を実現する PCM 仕様（相変化温度と厚み）を 決定できる線図を開発した。今後は、実測データとの照合による 精度検証を進め、線図の拡充を図る必要がある。

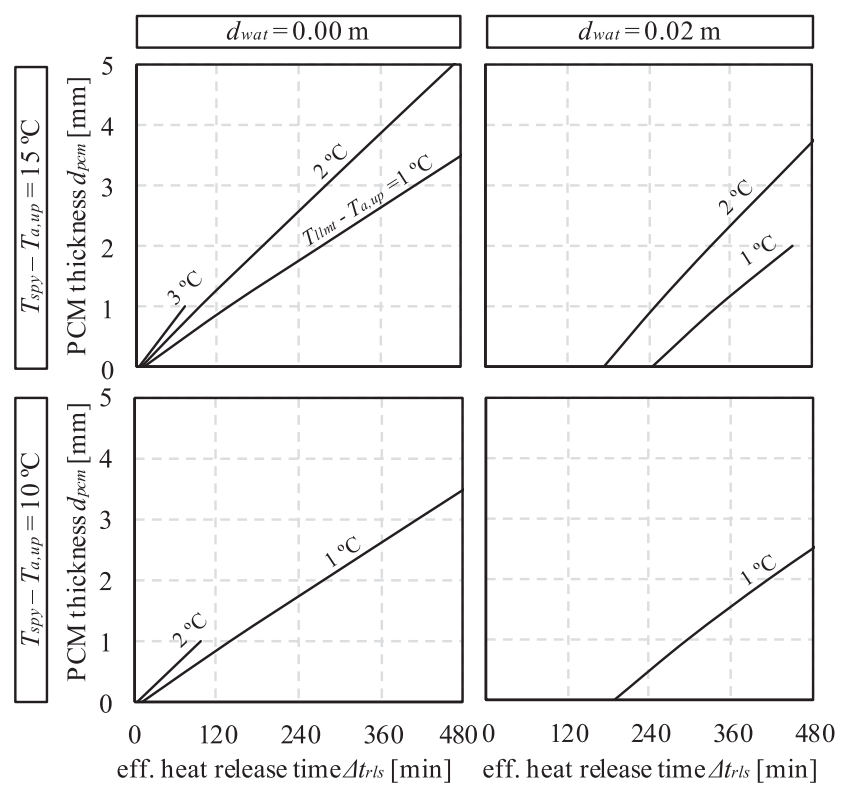

Fig.14 optimum pcm thickness $\left(\boldsymbol{\alpha}_{c, b k}=2 \mathrm{~W} /\left(\mathrm{m}^{2} \cdot \mathrm{K}\right), \boldsymbol{T}_{a, b k}=\boldsymbol{T}_{a, u p}-20\right)$
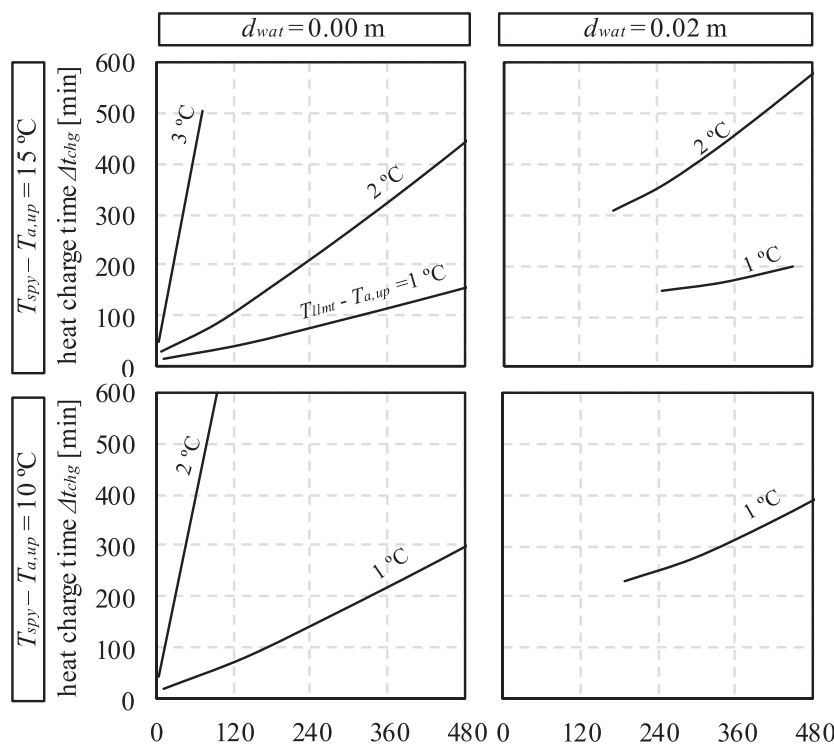

eff. heat release time $\Delta t_{\text {rls }}[\mathrm{min}]$ eff. heat release time $\Delta t_{r l s}[\mathrm{~min}]$

Fig.15 optimum heat charge time $\left(\alpha_{c, b k}=2 \mathrm{~W} /\left(\mathrm{m}^{2} \cdot \mathrm{K}\right), \boldsymbol{T}_{a, b k}=\boldsymbol{T}_{a, u p}-20\right)$
【記号一覧】

C : 熱容量

$\left[\mathrm{J} /\left(\mathrm{m}^{2} \cdot \mathrm{K}\right)\right]$

$d$ : 厚さ

$g$ : 重力加速度

[m]

Gr : グラスホフ数

$\left[\mathrm{m}^{2} / \mathrm{s}\right]$

$l$ : 長さ

$N u$ : 平均ヌセルト数

$\operatorname{Pr} \quad$ : プラントル数

$Q$ ：熱量

$R$ ：熱抵抗

$R a$ : レイリー数

$t \quad$ : 時間

$T$ : 将来の温度

$T^{*} \quad$ : 現在の温度

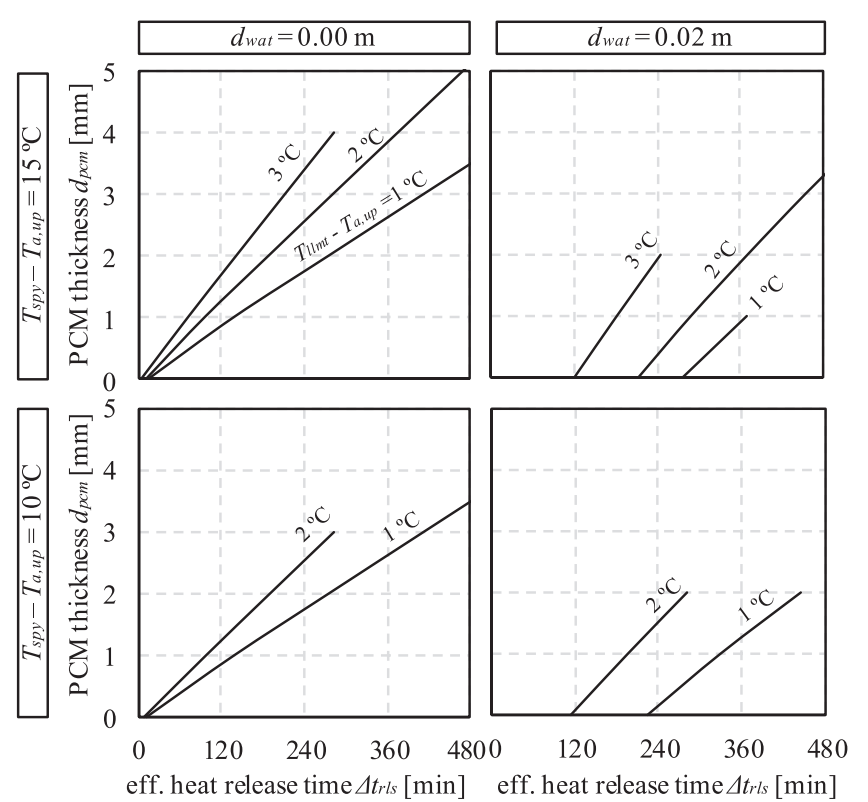

Fig.16 optimum pcm thickness $\left(\alpha_{c, b k}=8 \mathrm{~W} /\left(\mathrm{m}^{2} \cdot \mathrm{K}\right), \boldsymbol{T}_{a, b k}=\boldsymbol{T}_{a, u p}-20\right)$
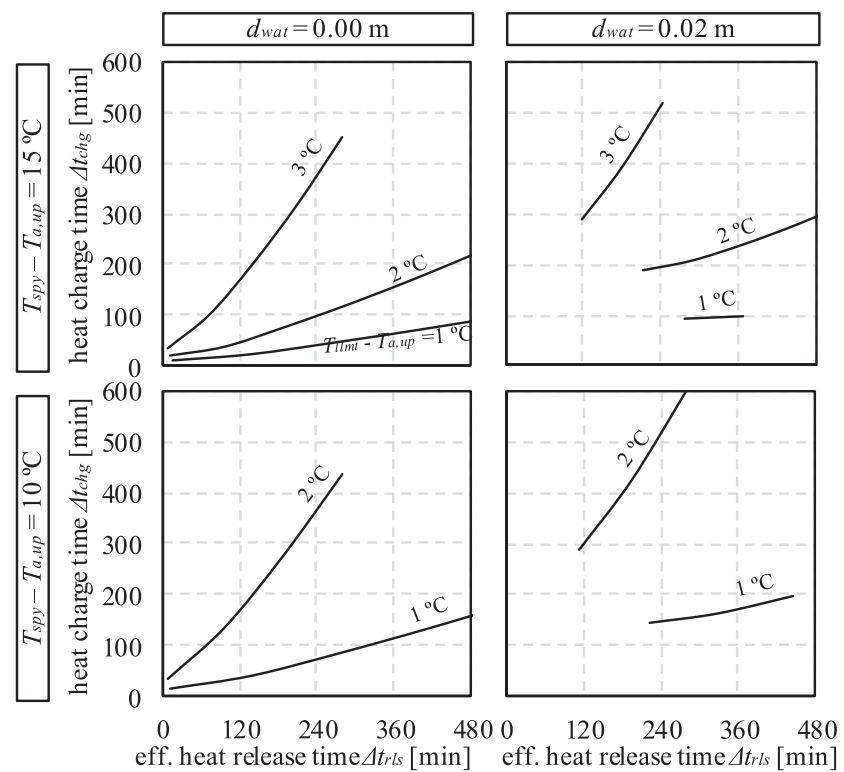

Fig.17 optimum heat charge time $\left(\boldsymbol{\alpha}_{c, b k}=8 \mathrm{~W} /\left(\mathrm{m}^{2} \cdot \mathrm{K}\right), \boldsymbol{T}_{a, b k}=\boldsymbol{T}_{a, u p}-20\right)$ 
$Q$ ：熱量

$R$ ：熱抵抗

$R a$ : レイリー数

$t \quad$ : 時間

$T$ : 将来の温度

$T^{*} \quad$ : 現在の温度

$\alpha$ : 熱拡散率

$\alpha_{c} \quad$ : 対流熱伝達率

$\beta$ : 体積膨張率

$\Delta t \quad$ : タイムステップ

$\eta_{s t b}$ : 安定化効率

$\lambda$ ：熱伝導率

$v \quad$ : 動粘性係数

$\left[\mathrm{J} / \mathrm{m}^{2}\right]$

$\left[\mathrm{m}^{2} \cdot \mathrm{K} / \mathrm{W}\right]$

$\left[{ }^{\circ} \mathrm{C}\right]$

$\left[{ }^{\circ} \mathrm{C}\right]$

$\left[\mathrm{m}^{2} / \mathrm{s}\right]$

$\left[\mathrm{W} /\left(\mathrm{m}^{2} \cdot \mathrm{K}\right)\right]$

$\left[\mathrm{s} /\left(\mathrm{J} / \mathrm{m}^{2}\right)\right]$

$[\mathrm{W} /(\mathrm{m} \cdot \mathrm{K})]$

$\left[\mathrm{m}^{2} / \mathrm{s}\right]$

\section{Subscripts:}

$a$ : 空気

a,up : 床上空気

$a, b k$ : 床下空気

$a m b$ : 周辺

$b k$ : 床下表面

c : 低温側

chg : 蓄熱時間

cor : 補正值

flr : 床

$f r z$ : 凝固点

$h$ : 高温側

llmt : 床表面下限温度

\section{謝辞}

本研究は、2014 年度早大理工総研・JX エネルギー（当時）FS 研 究助成の研究成果をさらに発展させたものです。また、PCM 相変化 時の非定常伝熱計算手法に関しては工学院大学 富樫英介先生に助 言を頂きました。ここに感謝の意を表します。

\section{参考文献}

1) Glass \& Architecture Winter 1999, Asahi glass Co.,Ltd., 1999 (in Japanese) Glass \& Architecture Winter 1999, 旭硝子, 1999

2) JSME Data Book, Heat Transfer $5^{\text {th }}$ Edition, JSME, 2009 (in Japanese) 伝熱工学資料 改訂第 5 版, 日本機械学会, 2009

3) Serikawa Mao, Saeki Tomohiro, Tatebayashi Keisuke, Choi Youngjin , Mae Masayuki: A new phase-change material experimental method and thermal behavior calculation method, Journal of Environmental Engineering (Transactions of AIJ), Vol. 82, No. 740, pp.853-862, 2017.10 (in Japanese)

芹川真緒, 佐伯智寛, 館林恵介, 崔榮晋, 前真之: 潜熱蓄熱材の熱特性の測定 法および熱的挙動の計算法に関する研究，日本建築学会環境系論文集，第 82 巻, 第 740 号, pp.853-862, 2017.10

4) Takeda Hitoshi, Nakayama Takashi, Iriguchi Yasunao: Application of phase change materials to housing heating : Development of heating equipment made of phase change materials with nylon-polyester filler and study of utilization, Journal of Architecture, Planning and Environmental Engineering (Transactions of AIJ), Vol. 67, No. 551, pp.53-59, 2002.1 (in Japanese)

武田仁, 中山卓士, 入口泰尚：潜熱蓄熱材 $(\mathrm{PCM})$ の住宅暖房への適用：ナ イロンポリ充填型PCM 暖房装置の開発とその利用方法の検討, 日本建築学 会計画系論文集，第 67 巻，第 551 号,pp.53-59, 2002.1

5) Takeda Hitoshi and Yamamoto Misho: Application of phase change materials to housing heating : Production and verification of effectiveness of wall-mounted heating system using pcm, Journal of Architecture, Planning and Environmental Engineering (Transactions of AIJ), Vol. 67, No. 558, pp.43-48, 2002.8 (in Japanese) 武田仁, 山本未生: 潜熱蓄熱材 $(\mathrm{PCM})$ の住宅暖房への適用：潜熱蓄熱材利
用壁式暖房装置の製作と有効性，日本建築学会計画系論文集，第 67 巻，第 558 号, pp.43-48, 2002.8

6) Takayama Yukako, Mori Taro, Ishidoya Yuji, Matsunaga Junichiro, Hayama Hirofumi And Kikuta Koki: Development of system for reducing fresh air load by using solar collector and pcm in cold region numerical analysis of system efficiency by using characteristics of elements, Journal of Environmental Engineering (Transactions of AIJ), Vol. 80, No. 708, pp.117-126, 2015.2 (in Japanese) 高山裕香子, 森太郎, 石戸谷裕二, 松永潤一郎, 羽山広文, 菊田弘輝: 寒冷 地における太陽熱空気集熱器と潜熱蓄熱材を組み合わせた外気負荷削減装 置の開発 個別要素の特性によるシステム効果の数值解析, 日本建築学会 環境系論文集, 第 80 巻, 第 708 号, pp.117-126, 2015.2

7) Kusama Yuka, Ishidoya Yuji, Miura Makoto, Miyazaki Tomohito: A study on passive thermal storage effects of pcm plastered wall: An examination of the basic thermal performance test method, indoor environmental improvements, and energy saving effects of PCM plastered wall in the experimental module, Journal of Environmental Engineering (Transactions of AIJ), Vol. 81, No. 722, pp.367-374, 2016.4 (in Japanese)

草間友花，石戸谷裕二，三浦誠，宮崎智仁：潜熱蓄熱(PCM)内装左官材のパ ッシブ蓄熱効果に関する研究 基本的熱性能試験の測定方法及び実験棟に おける環境改善効果と省エネルギー効果に関する検討, 日本建築学会環境 系論文集, 第 81 巻, 第 722 号, pp.367-374, 2016.4

8) Takamura Hideki, Miyaji Kai, Yamaha Motoi: Utilization of a PCM Storage Tank Installed Under the Floor in a Detached House Part 3 Performance Evaluation of a Heating System Using PCM Installed Under the Floor of a Detached House in a Warm District, Technical papers of annual meeting, The Society of Heating, AirConditioning Sanitary Engineers of Japan, pp.209-212, 2016.9 (in Japanese) 高村秀紀, 宮路凱, 山羽基: 住宅における床下に設置する潜熱蓄熱材の利 用に関する研究(第 3 報)温暖地の戸建住宅における潜熱蓄熱材を利用した 床下暖房システムの性能評価，空気調和・衛生工学会大会学術講演集文集, pp.209-212, 2016.9

9) Shinozaki Masahiro, Watanabe Tsohiyuki, Ryu Yuji, Hayashi Tetsuo: Proposal of design guideline and operation guidance of latent/sensible heating storage system, Journal of Environmental Engineering (Transactions of AIJ), Vol. 69, No. 579, pp.29-36, 2004.5 (in Japanese)

篠崎正弘, 渡辺俊行, 龍有二, 林徹夫: 潜熱・䡩熱式電気床暖房システムの 設計・運転指針に関する提案，日本建築学会環境系論文集，第 69 巻，第 579 号, pp.29-36, 2004.5

10) Takase Kozo, Mae Masayuki, Akamine Yoshihiko, Kono Ryohei, Satoh Makoto, Sakamoto Yuzo: Study on the effective use of floor heating system, using heat pumps and pcm in houses: Part 1 summary of the system and evaluation by survey, Journal of Environmental Engineering (Transactions of AIJ), Vol. 77, No. 673, pp.175-184, 2012.3 (in Japanese)

高瀬幸造, 前真之, 赤嶺嘉彦, 河野良坪, 佐藤誠, 坂本雄三: 実在住宅にお ける温水ヒートポンプ熱源を利用した潜熱蓄熱式床暖房システムの効果的 な運転に関する研究 その 1 システムの概要と実測による評価, 日本建 築学会環境系論文集, 第 77 巻, 第 673 号, pp.175-184, 2012.3

11) Fujita Koji, Iwamae Atsushi, Matsushita Takayuki, Nakagawa Hiroshi, Yokoyama Hiroshi, Ishizu Kyoji: A study on crawl space heating with latent thermal storage materials, Journal of Environmental Engineering (Transactions of AIJ), Vol. 73 No. 626, pp.479-486, 2008.4 (in Japanese)

藤田浩司，岩前篤，松下敬幸，中川浩，横山弘嗣，石津京二：潜熱蓄熱材を 用いた蓄熱型床下暖房に関する研究, 日本建築学会環境系論文集, 第 63 巻, 第 626 号, pp.479-486, 2008.4

12) Nagano Katsunori, Takeda Sayaka, Mochida Tohru, Shimakura Kazumi, Nakamura Takuji: Study on floor supply air conditioning system storing cold energy for building structure and granules including phase change material : Part 1 construction of a small-scale experimental system and the thermal characteristics, Journal of Environmental Engineering (Transactions of AIJ),Vol. 69, No. 579, pp.21-28, 2004.3 (in Japanese)

長野克則, 武田清香, 持田徹, 嶋倉一實, 中村卓司: 粒状潜熱蓄熱材を適用 した躯体蓄熱床吹出し空調システムに関する研究：第 1 報 小型実験シス テムの構築およびその蓄放熱特性, 日本建築学会環境系論文集, 第 69 巻, 第 579 号, pp.21-28, 2004.3

13) Ken-ichi Ishida: Simulation of the panel heating and cooling system with latent heat storage material, Techinical papers of annual meeting the SHASE of Japan, Oct. 1994 (in Japanese) 
石田建一：潜熱蓄熱パネルを用いたふく射冷房シミュレーション，空気調 和・衛生工学会学術講演会講演論文集, pp.1041-1044, 1994.10

14) K. Darkwa and P. W. O Callaghan: Simulation of phase change drywalls in a passive solar building, Applied Thermal Engineering, Vol. 26, Issue 8-9, pp. 853858, June 2006

15) Ylenia Cascone and Marco Perino: Estimation of the thermal properties of PCMs through inverse modelling, Energy Procedia, Vol. 78, pp. 1714-1719, Nov. 2015

16) Vasken Dermardiros, Yuxiang Chen and Andreas K. Athienitis: Modelling of an active PCM thermal energy storage for control applications, Energy Procedia, Vol. 78, pp. 1690-1695, Nov. 2015

17) Helmut E. Feustel: Simplified Numerical Description of Latent Storage Characteristics for Phase Change Wallboard, May 1995

18) Iguchi Masato and Sakamoto Yuzo: Analysis of heating load using the thermal simulation, Journal of Environmental Engineering (Transactions of AIJ), Vol. 78, No. 694, pp.939-945, 2013.12 (in Japanese)

井口雅登，坂本雄三：温熱シミュレーションによる熱負荷の分析，日本建 築学会環境系論文集, 第 78 巻, 第 694 号,pp. 939-945, 2013.12

\section{注}

注 1）厳密には相変化に伴う熱容量の変化に関する誤差補正だけではなく熱 伝導率の変化に関しても誤差補正を行う必要がある。しかし、この誤差は 以下に示すように極めて小さい。例えば本稿 Fig.5 の Case A の構成におい て、PCM からフローリングへの熱抵抗は、固相では $0.081 \mathrm{~m}^{2} \cdot \mathrm{K} / \mathrm{W}$ 、遷移相
では $0.074 \mathrm{~m}^{2} \cdot \mathrm{K} / \mathrm{W}$ である。従って、相変化を無視することの熱流の誤差は 約 $10 \%$ となる。一方、本モデルではタイムステップを 1 秒としており、仮 に PCM とフローリングの温度差が $10{ }^{\circ} \mathrm{C}$ であったとしても、 1 秒あたりの 温度変化は $0.018^{\circ} \mathrm{C}$ となる（フローリングの熱容量は $7.5 \mathrm{~kJ} /\left(\mathrm{m}^{2} \cdot \mathrm{K}\right)$ ) 。従っ て、このときに熱流の誤差がもたらす温度変化の誤差は $0.0018^{\circ} \mathrm{C}$ 程度であ る。加えて、このような誤差の正負は相変化の方向によって逆となり打ち 消し合うため、計算の進行によって大きく蓄積するものでは無い。以上の 理由により、本研究では上記の誤差補正は省略した。

注 2) 無次元数の計算のためには熱媒の温度などが必要となる。厳密な值を得 るためには各タイムステップにおいて収束計算を行う必要があるが、本モ デルではタイムステップを 1 秒としており、誤差は小さいと予想できるた め、前タイムステップ (1 秒前) の温度を用いることとした。

注 3) 本研究で狙う運用は以下のとおりである。燃料電池やソーラーパネルな どの分散型エネルギーや再生可能エネルギーの積極的な導入が推奨されて おり、今後は需要家へのエネルギーフローを考慮したシステムの開発が不 可欠となると考えられる。この問題に対しては需要家がエネルギーの供給 量に応じて需要量を変動させるデマンドレスポンスによる負荷調整が期待 されている。本研究では、比較的短い時間のピークシフトを目的に PCM に よる蓄放熱を行うことを前提としているため、蓄熱時間帯は居住者の在室 時間帯となり、設計上は室温を一定值として取り扱う。従って、本文に記 載の外出時の蓄熱という運用や、あるいは、安価な深夜電力の活用を目的 に就寝時に自然室温の中で蓄熱を行い、起床後の放熱を期待するような運 用の場合には、本図はそのままでは利用できない。 


\title{
Jun NAKAGAWA ${ }^{* 1}$ and Shin-ichi TANABE ${ }^{* 2}$
}

\author{
${ }^{* 1}$ Grad. Student, Dept. of Creative Science and Engineering, Waseda University, M.Eng. \\ ${ }^{*}$ Prof., Dept. of Creative Science and Engineering, Waseda University, Dr.Eng.
}

Many studies have been conducted on PCMs' material character, thermal comfort, and energy savings. However, PCM is more expensive than most sensible heat storage materials (e.g., water and concrete). Thus, it is necessary to develop a relatively cheaper solution.

A floor heating system is developed using PCM and an under-floor chamber. A home air conditioner or a pneumatic solar thermal collector is used as a heat source. By sending warm air into the insulated under-floor chamber, heat is transferred to a storage tank adhered to the flooring material. The heat storage layer is composed of PCM on the flooring side and a water-filled layer on the chamber side. A spring-effect heat-conductive metal plate (SHP) adheres the heat storage layer to the backside of the flooring material. Made of an inexpensive sheet metal bent into a certain shape, the SHP realizes a spring effect with the strength needed to ensure adhesion. By installing this system between floor joists, it becomes possible to install a heat storage layer adhered to the backside of the floor without changing the ordinary floor structure.

In addition, we present a simulation and a diagram for design purposes. A floor, composed of phase-change materials and a water pack, is represented using a mass-point model. The model formulated with differential equations is solved using the backward difference method. For the four cases, time-series fluctuation of heat storage and heat release is simulated. Regarding the phase change material, we express the nonlinear tendency of heat release and storage.

Line charts for the proposed system are presented. We define system optimization, which is to maximize the length of time the floor surface temperature is stably maintained with respect to the unit heat storage amount. By conducting simulations using the model of Chapter 3, we develop diagrams that derive the PCM specifications (i.e., phase-change temperature and thickness) based on the designed room temperature and the floor surface temperature lower-limit value. 